\title{
The Really Big Contradiction: Homeownership Discourses in Times of Financialization
}

\author{
Forthcoming in: Housing Studies \\ Erlend Fikse \& Manuel B. Aalbers \\ KU Leuven/University of Leuven \\ Division of Geography \& Tourism \\ Celestijnenlaan 200E bus 2409 \\ B-3001 Leuven \\ BELGIUM \\ erlend-fikse@,hotmail.com \\ manuel.aalbers@,kuleuven.be
}

\begin{abstract}
Belgium is a typical homeowner society where homeownership is not only the largest but also the 'normalized' form of tenure. The origins of the Belgian homeownership ideology go back to the early days of industrialization but the discourses surrounding the ideology are reproduced in the $21^{\text {st }}$ century. Our investigation of the largest region of Belgium, Flanders, reveals four main homeownership discourses: affordable homeownership, conservative housing finance, assetbased welfare and tenure neutrality. With a nod to Kemeny's 'The Really Big Trade-Off Between Homeownership and Welfare', we demonstrate that there is also a 'Really Big Contradiction' between the discourses that support homeownership as the 'normalized' form of tenure in Belgium and the reality of declining affordability, progressively less conservative housing finance, the fractions and inequalities of housing-based wealth, and the lack of tenure neutrality. In short, we argue that the financialized homeownership model is undermining the stability of homeowner realities and practices, but not so much the discourses and ideologies that support and reinforce the homeowner society.
\end{abstract}

Key words: Flanders, Belgium; homeownership; ideology; discourse; asset-based welfare; housing affordability; financialisation 


\section{Introduction}

Homeownership has become a dominant ideology and tenure type in industrialized countries, with many developing into 'homeowner societies', in which the majority of the households are owner-occupiers (Ronald, 2008). Popular discourses on homeownership are widely present in (predominately) Anglophone countries, such as the United Kingdom, the United States, Australia and Ireland, which have evolved into 'nations of homeowners' (Saunders, 1990). Popular proverbs attest to this fact, equating homeownership with happiness, such as 'an Englishman's home is his $[\mathrm{sic}]$ castle' or 'the American Dream' (Kwak, 2015; Norris, 2016; Ronald, 2008; Saunders, 1990; Smith, 2019). Today, these countries are understood as 'mature homeowner societies' where homeownership rates have declined since the recent global financial crisis (GFC). Housing affordability and access to mortgage loans is negatively affected by the combined effects of neoliberalization and financialization, further exasperated by the spread of casual labour, especially among younger cohorts, which frustrates their access to mortgage loans (Aalbers, 2015; Forrest \& Hirayama, 2018; Ronald, 2008; Schwartz \& Seabrooke, 2009).

The different housing tenures-here simplified as homeownership, social renting and private renting - are typically assumed to be stable, but the meaning and realities of these tenures shift over time, and although there are 'common national trajectories' (Fernandez \& Aalbers, 2016; Hay, 2004) in these shifts there are also continued differences between places. Whereas homeownership is typically seen as the most desired tenure, the construction of this desire is based on a normalization of outright homeownership, which is increasingly rare in most Anglophone and European countries. In this context, Forrest and Hirayama (2015: 233) have argued that:

There is an increasing disconnect between the lived experience of home ownership and its form as a financial asset - between the 'social project' of home ownership, which dominated much of post war political and policy rhetoric and the neoliberal economic project.

Whereas homeownership ideals used to be connected primarily to ontological security but also thrift, they now are increasingly also connected to ideas of investment-from merely a store of wealth to also a source of income (Aalbers, 2008; Forrest et al., 1990). Parallel to the transformation of the private rental (Kemp, 2015; McKee et al., 2017; Ronald \& Kadi, 2018) and social rental sectors (Boughton, 2018; Hodkinson, 2019), the owner-occupied sector is also in transformation. This has tempted some to speak of 'late' (Forrest \& Hirayama, 2018) or even 'post-homeownership societies' (Ronald, 2008; Ronald \& Kadi, 2018). On the one hand, decades of neoliberalization and financialization have 'undermined the integrative and stabilising dimensions of home ownership' (Forrest \& Hirayama, 2015: 241), but on the other '[m]ortgaged homeownership increasingly is there to keep mortgage and financial markets going, rather than 
being facilitated by those markets' (Aalbers, 2015: 52). Our contribution to this literature is not only to study the Belgian case-which remains relatively understudied - but also to show how these contradictions become visible in policy discourses.

Belgium also has been promoting homeownership as the favoured model of tenure for a long time (De Decker, 2013; Meeus \& De Decker, 2013). Since the first housing law of 1889, homeownership has been proclaimed and practised as the preferred model of tenure in Flanders and throughout Belgium (De Decker, 2011). Different systems of support and housing grants helped aspiring homeowners in building or buying their own house. Throughout Belgium's history, homeownership has been promoted by the Catholics, the most powerful fraction of society. During Belgium's early industrialisation they already tried to keep workers out of the cities and keep them 'under the town's church tower'. This has led to a country where approximately 70 to 75 per cent of the households are homeowners. Furthermore, during state reforms in 1980 and 2014, the competence of first, housing and then, property taxes was transferred to the regions of Flanders, Wallonia and Brussels (Haffner \& Winters, 2016). In this paper, we focus on Flanders, the largest of the three regions and home to over 6.6 million people (58\% of the Belgian population).

The traditional emphasis on homeownership has been well documented in the literature (for Belgium, see section 3), and this paper focuses on the contemporary policy and stakeholder discourses of homeownership. Rather than focusing on media or popular discourses of homeownership (e.g. Gurney, 1997; Munro, 2018), we explicitly focus on the reproduction of homeownership discourses by policymakers, including political parties but also other key players in policy debates. The study consists of 14 in-depth interviews with representatives of major political parties, government and the financial sector. In this paper we discuss four contemporary discourses of homeownership as the model of tenure in Flanders: house price inflation and affordability, conservative housing finance, asset-based welfare, and tenure neutrality. By analysing how these discourses are reproduced by the main political parties and within state institutions, we expose the contradictions between the nature of the discourses that support homeownership and the reality of declining affordability, progressively less conservative housing finance, the fractions and inequalities of housing-based wealth, and the lack of tenure neutrality.

The paper is structured as follows. The next section introduces the literature on the ideologies and discourses of homeownership, focusing on the reproduction of these discourses. In section 3 we briefly introduce the Belgian homeownership model, arguing that homeownership has long been favoured as the 'normalized' form of tenure. In section 4, we present the results of our discourse analysis and begin to answer the question: What are the contemporary policy and political discourses of homeownership as the model of tenure in 
Flanders? In the concluding section we argue that the financialized homeownership model is undermining the stability of homeowner realities and practices in Flanders, while the discourses and ideologies that support and reinforce the Belgium homeowner society remain strong.

That is, our contribution to the literature is to demonstrate that there is not only a 'Really Big Trade-Off Between Homeownership and Welfare', as Kemeny (1981) has argued, but that there is also a 'Really Big Contradiction' between the nature of the discourses that support homeownership as the 'normalized' form of tenure in Belgium and the reality of financialized homeownership. Flanders and Belgium are by no means 'extreme cases' of financialized homeownership - the financialization of homeownership has progressed much further in many Anglophone and Scandinavian countries as well as the Netherlands — and we suggest that if the contradictions are as visible in a moderately financialized homeownership society as Belgium, they also may be present, albeit in country-specific ways, in equally or more financialized homeownership societies.

\section{Discourses of Homeownership}

In this section we will first discuss the two main, yet opposing, viewpoints on the nature of homeownership: either as something 'natural' that people want or as something that is socially constructed. We also discuss that while the idea of 'asset-based welfare' (ABW) appears to support the first concept, the reality of ABW fits the second one better. In the second part of this section, we discuss the methodology for studying the reproduction of homeownership discourses in Flanders.

\subsection{Homeownership: Natural or Socially Constructed?}

There are different political and academic positions regarding the drive towards homeownership. On the one hand, it is argued that humans have a sort of 'natural' appeal for owning property, and that aspirations towards owning a home cannot be fully understood as sole interests of capital accumulation. Especially Peter Saunders (1990) advanced this argument, illustrating that in the UK homeownership expanded during a time marked by a very high supply of social housing. Thus, he argued, when people are financially capable, they will become homeowners for both financial and emotional reasons. These claims are partially supported by quantitative and qualitative studies that demonstrate that homeowners are often more satisfied with their housing than tenants (Diaz-Serrano, 2009; Elsinga \& Hoekstra, 2005; Hiscock, Kearns, MacIntyre, \& Ellaway, 2001; Hoolachan, McKee, Moore, \& Soaita, 2017; Rohe \& Stegman, 1994). 
Homeowners may see their home explicitly as an asset (Aalbers, 2019; Forrest \& Hirayama, 2015; Malpass, 2008; Smith et al., 2009) or may prioritize the ontological security of a home over asset building (Dupuis \& Thorns, 1998; Easthope, 2004).

However, the results of these studies should not be taken at face value: typically, people who become homeowners already enjoyed a stronger socio-economic position before. Moreover, in societies where homeownership is the dominant tenure, renting may be stigmatized and respondents on surveys and interviews may reproduce these stigmas or the more favourable discourses of homeownership. Furthermore, lower rates of homeownership in rich countries such as Germany and Austria weaken the explanatory power of this hypothesis and suggest that the desire for homeownership is socially and politically constructed. Thus, it is important to find a balance between the natural and the constructed nature of homeownership preferences rather than seeing them as a dichotomy (Ronald, 2008).

On the other hand, a seemingly unlikely coalition of Marxists and Foucauldians emphasize the role of capital and discourse in creating the conditions for (financialized) homeownership to become 'normalized'. The capitalist process needs continuous accumulation where housing becomes commodified; therefore, mortgaged homeowners are necessary in order for capital to find more investments (Aalbers, 2008), with homeowners serving as often un/ conscious subjects to hegemonic capital interests (Berry, 1986; Di Feliciantonio, 2016; Kemeny, 1981; Langley, 2006). This creates a new set of power relations in society (Lazzarato, 2012), where mortgagors are dependent on the mortgagees for acquiring the basic need of housing and homeownership (García-Lamarca \& Kaika, 2016). In other words, the 'prejudice' and normalisation of tenure and homeownership take place chiefly along the interests of capital and power (Gurney, 1999). The financialized model of housing not only reproduces homeownership as the dominant form of tenure, but also produces increasingly indebted homeowners.

At its most basic, a home provides necessary shelter; however, outright homeowners also have an added benefit, as they do not need to pay rent or pay off their mortgage and, therefore, have a form of welfare in the asset with income in-kind (Doling \& Ronald, 2010). This idea is fundamental to the concept of $\mathrm{ABW}$, which is furthered developed through life-cycle theory, which is used to estimate a person's ability to earn money during their the life-course. Taking up a mortgage at a younger age becomes a strategy for earning more throughout one's lifetime and ensuring a rent- and mortgage-free life during retirement.

Although ABW may work as a general idea and for some parts of the population, the success of $\mathrm{ABW}$ is dependent on many factors, and not everyone can become an outright homeowner before retiring. Many unforeseen events can delay or terminate homeownership (e.g., divorce, long-term unemployment or serious illness). Ironically, the stability of ABW relies 
on strong welfare states to support a stable income during times of trouble rather than necessarily providing an alternative to it. Furthermore, the volatility and overall instability in house prices also put into question the sustainability and ethical consequences of relying on $\mathrm{ABW}$ (Aalbers, 2016; Dewilde \& Ronald, 2017).

Moreover, changes in labour markets have made income less secure, whereas increasing house prices have made access to homeownership more difficult for younger generations. As a result, homeownership rates in many countries will decline or are already declining (Arundel \& Doling, 2017; Whitehead, Scanlon, \& Lunde, 2014; Whitehead \& Williams, 2017). ABW may help a part of the population to build up substantial wealth, but it is very unlikely that everyone is able to do so. Moreover, those unable to attain homeownership encounter a 'double disadvantage' as they are excluded by social norms and expectations but also are more likely to face poverty at a later age (Dewilde \& Raeymaeckers, 2008). Therefore, ABW cannot be seen as a universal method of securing welfare for all retired households and may actually increase inequality between different social groups (Aalbers, 2016; Arundel, 2017; Montgomerie \& Büdenbender, 2015; Ronald, 2008).

\subsection{Researching Homeownership Discourses}

Discourses have many different meanings. We see a discourse as 'the ways in which social realities are constructed through communicative practices' (Angermuller, 2015: 510). In a social constructivist perspective, discourses produce and reproduce realities. We focus on how actors or agents make meaning of as well as reproduce the ideology of homeownership, both orally and in written text. Discourse analysis relies on a range of different - and sometimes contradictingtheories and epistemologies. From these different positions, we take Habermas' (1985) point that normative standards are inherent to discourse, which explains why some ideas are considered more true, rational and acceptable, and Lyotard's (1984) insistence on the unresolvable tensions and contradictions that make rational agreement impossible. In addition, we also rely on the Foucauldian and critical realist notion that discourses are always embedded in power structures (Foucault, 1972; Fairclough, 1992). Indeed, unequal power relations are produced and reproduced through discourses, as will be demonstrated in the case of homeownership discourses. We are particularly interested in 'the critical tensions between how discourses should operate and how they actually do operate' (Angermuller, 2015: 511, emphasis in original).

There are many different types of discourse analysis, some more strongly related to different strands of discourse theory than others. Our theoretical position on discourse does not square well with the more quantitative and the more linguistic-oriented approaches. Instead, if 
follows a practice- and context-oriented approach, which is less formulaic or formalized and sees discourse less as something to count or deconstruct linguistically and more as a tool to make sense of how ideas are reproduced by stakeholders, i.e. a space for sense-making and possibly also agreement-making (Habermas, 1985). Rather than following a systematic critical discourse analysis, we are inspired by a more loose idea of discourses within interpretive policy analysis that focuses on points of conflicts and contradictions within and between discourses (Yanow, 2000). This approach may not work well for analysing all kinds of discourses but is particularly well suited for situations where discourses are widely shared within a society (Keller, 2005), as is the case with homeownership discourses in Belgium. We do not present a historical analysis of the formation of homeownership or how it became the norm in Belgium - although we discuss the existing literature on this topic in section 3-but focus on the reproduction of such discourses by policymakers and other key stakeholders. Like McKee et al. (2017), we are interested in the tensions between homeownership as the normalized ideal and the realities of increasingly constrained access to homeownership.

In order to study the reproduction of homeownership discourses, we examined policy documents and interviewed 14 policy stakeholders in the Flemish housing field. Then, we analysed the discourses that support — and potentially frustrate - the reproduction of the ideology and realities of homeownership. We first scrutinized the housing sections of the 2014 election programmes as well as the relevant information of the websites of political parties, in order to identify discourses that support the promotion of homeownership. In addition, we analysed the Housing Policy Plan of Flanders (Woonbeleidsplan Vlaanderen, 2018) as well as official publications of the National Bank of Belgium (NBB), such as the Financial Stability Report. The review of policy and financial documents aims at achieving three key goals: to understand the reproduction of policy discourses; to understand the normalization of increasing indebtedness and mortgaging of households; and to prepare a customized semi-structured interview guide for each interviewee.

In the next stage, we interviewed the housing spokespersons of the four main political parties in Flanders as well as managers in the housing and housing finance policy fields, including representatives of the Flemish Housing Agency, the Flemish Housing Advisory Board, the National Bank of Belgium, Febelfin (the financial sector's umbrella organisation), the Professional Mortgage and Credit Lenders Association (BVK), the Christian Labour Union, the umbrella organisation for social housing agencies in Flanders (VHH), the Support Point Housing (an official interuniversity research and advisory board to the Flemish government). The latter was represented by a professor of housing policy who is the research leader of the Support Point. Finally, we interviewed another professor, a member of the Support Point, and a key expert on 
Flemish housing policies. The four political parties are either currently in power as part of the ruling coalition or have been in power in the past two decades. The in-depth interviews were designed as 'conversations with a purpose' (Flowerdew \& Martin, 2005), which means that the interviews have the purpose of getting information from the interviewee in order to answer the research question. The interviews took place at the offices of the interviewees and lasted between 40 and 90 minutes each. Prior to the conversation, the interviewees allowed us to use nonanonymized interview quotes. They were given the possibility to withdraw their permission after the interview but none of them did so.

All the interviews were recorded and transcribed. Each sentence and paragraph were then analysed and labelled with potential discourse markers. Discourses were not predefined but emerged out of a cross-reading of the different policy documents and transcripts. In the end, we were able to distinguish between four main discourses and several sub-discourses. Some subdiscourses appear to support two of the main discourses at the same time, and have been labelled accordingly, but will not be discussed in this paper due to space limitations (for more information, please consult AUTHOR, 2019). This was a process of trial and error. During the coding work, if the statement in the sentence and paragraph did not match any of the discourses that were already identified, a new discourse or a sub-discourse to one of the main discourses was created. This approach made it possible to analyse the discourses held by the different stakeholders as well as the specific information contained within each discourse.

\section{Homeownership in Belgium}

To paraphrase Saunders (1990), Belgium is 'a nation of homeowners' (De Decker \& Dewilde, 2010). Already in 1850, homeownership was considered a political goal for reasons of social stability, prosperity and avoidance of social unrest (Goossens, 1983; Smets, 1977). Ever since the first housing law of 1889, it has been promoted as the favoured form of tenure, inspired by the Napoleonic Code's emphasis of private property rights as one of the fundamentals of civil society (De Decker, 2011) and developed further with a focus on single-family dwellings, with the aim of creating stable family. This was in line with the 1891 Catholic Social Teaching, also known as Rerum Novarum, and the 1931 Quadragesimo Anno (Mougenot, 1988). In Catholic doctrine, private property rights are taken to be the natural state of organizing society. The right to property is therefore something that is said to belong to each individual man (sic). As a result, in Belgium the owner-occupied, single-family house was seen as the best way to organize housing for the nuclear family, in line with dominant theological ideas (Mougenot, 1988). 
Faced with the economic and social crisis of the 1930s, the Belgian government chose to continue supporting homeownership, in line with these Catholic principles. The focus was on houses in the urban fringe and rural areas, with the aim to disperse workers across the country and avoid concentration of large unemployed populations in urban centres and all the negative consequences such as alcoholism and moral decay. Catholic morality expressed through housing policy was thus an important strategy. In line with those ideas a mortgage loan was not primarily considered as being indebted but rather as something that would discipline workers and increase their reliability; they would avoid riots and strikes in order to be able to pay the monthly instalments on their mortgage (Smets, 1977; cf. the UK, Forrest et al., 1990). Successive governments promoted homeownership as a moralizing and disciplining strategy to resist civil unrest and to protect political conservatism and the hegemony of Catholic thought.

Yet it was not only Catholic political forces that favoured homeownership; the Liberal Party historically also considered homeownership to be in line with liberal ideology (Witte, 1990). More recently, the former Liberal Prime Minister Verhofstadt (2002) made it clear that the party supports policies that aim for 100\% homeownership (De Decker, 2011). The Flemish Nationalist Party, N-VA, a relative newcomer to the Belgian scene but currently the largest party in Belgium, appears to mix Catholic and Liberal arguments in favour of homeownership. More recently, in 2007, the Socialist Party, the fourth of the large Flemish political parties, also declared itself within the pro-homeownership club:

Everybody has the right to a comfortable, qualitative and affordable dwelling. We want as many people as possible to own their house. This is the best guarantee for living well and it is the best way for pension savings. (Cited in De Decker, 2011: 1642)

Behind the ideology of supporting and favouring homeownership as the preferred model of tenure, important milestones have enabled its advance in Belgium and Flanders. In 1830-31, Belgium became an independent and liberal state that emphasized private ownership in their constitution (De Decker, 2011). The discourse on homeownership as the best type of tenure for promoting a stable society was already in the political realm around the 1850 s and became institutionalized in 1893, when voting rights were tied to homeownership (De Decker, 2011).

After World War I, individual grants were provided for rebuilding houses and further grants were provided to all individuals who became homeowners. In 1928 the 'social mortgage institution' (Woningfonds) was established to provide cheap loans to large families and continues to operate to today (De Decker, 2011). In 1948, the De Taye Act facilitated the rise of Belgium as a nation of mass homeownership. In the 1940s and 1950s, more than 350,000 grants were provided to facilitate homeownership (Buyst, 1992; Deschamps, 1997; Mougenot, 1988; Ryckewaert, 2011). In 2005, the federal government introduced the so-called Housing Bonus 
(Woonbonus), a mortgage interest relief scheme. After becoming responsible for housing policies in 2014, the Flemish government reduced the Housing Bonus by one-third, primarily as a budgetary measure. Renting, on the other hand, is often considered as not having any financial benefits. Whereas the social housing sector is small and somewhat marginalized, private renting is only supported by a small number of housing allowances targeted at low-income households that have been on social housing waiting lists for several years (Haffner \& Winters, 2016; Winters, 2013).

The strong promotion of and emphasis on homeownership in Belgium has produced and imposed a very strong cultural ideology on the Flemish. The ideal of an 'home of their own' has become a common phrase in day-to-day language (Meeus \& De Decker, 2013), and often Belgians are said to be 'born with a brick in their stomach'. Becoming a homeowner has become a major goal and people who are not, or not striving to become, homeowners are often stigmatized (Meeus \& De Decker, 2013). The long-standing discourse and promotion of homeownership, especially in the form of self-built housing at the urban fringes and in rural areas has led to vast urban sprawl across Flanders (Ryckewaert, 2011). Already in 1919, Vandervelde, a socialist leader, observed that Belgium could be considered one large suburb (De Decker, 2011). The promotion of suburban and exurban homeownership produced and consolidated an anti-urban attitude - that still lives on today-with a vast majority of the population preferring to live in suburbs (Kesteloot \& De Maesschalck, 2001). Becoming a homeowner is considered very important for the decision of having children, and homeownership is acknowledged as the only way to provide security of tenure, since the private rental sector is not considered a serious alternative (De Decker, 2001; De Decker, Meulemans, \& Geurts, 1997). For Flanders, the 2018 homeownership rate stands at $72 \%$, slightly down from $74 \%$ in 2005 . Yet whereas it increased from 85 to $90 \%$ for the highest income quintile, it decreased from 63 to $50 \%$ for the lowest and from 70 to $63 \%$ for the second-lowest quintile (Statistiek Vlaanderen, 2020).

\section{Flemish Homeownership Discourses}

Below we discuss the four main discourses that dominate the current reproduction of homeownership as the main tenure in Flanders: access and affordability, conservative housing finance, $\mathrm{ABW}$, and tenure neutrality. We illustrate each discourse with short interviews excerpts; more interview quotes can be found in the underlying study (AUTHOR, 2019). As we've explained in section 2.2, these discourses emerged out of a cross-reading of the different policy documents and interview transcripts. The four discourses that we distinguish serve as heuristic 
devices, a way of looking at —or, of organizing — reality rather than reality itself. These heuristic devices could have been constructed in a slightly different way and the number of four discourses is arbitrary as different discourses are made up, and supported by, different subdiscourses. It is not our goal to define a certain number of discourses but rather to show the contradictions within homeownership discourse as well as between homeownership discourse and the social reality of constrained access to homeownership.

\subsection{Affordable Homeownership}

Housing in Flanders and Belgium has become more expensive both in nominal and real terms, as testified by our interviewees and NBB document review (Du Caju et al., 2018; Hilgers, 2018):

If you just compute the affordability indicators, it tells you that housing is now much more expensive than 10, 15 years ago.... Yeah, housing has become more expensive, both in nominal and real terms. (Interview Dewachter, NBB)

Yet, there is no straightforward consensus that housing as such is unaffordable. As De Decker, a professor of housing, explains in the interview: 'From a pure economic point of view, the house price increases are not problematic; they can be explained.' This view is shared by many interviewees in this study, who nevertheless also acknowledge that there is a trend towards decreasing quality, access and affordability, and that uptake of mortgage debt has made lowincome households vulnerable and created a 'pocket of risk' (Du Caju, 2017; Du Caju et al., 2018).

As a response to the GFC of 2007-2009, Belgian banks enforced tighter loan-to-value ratios by mandating higher deposit requirements (Interviews Dewachter, NBB; Van Bulck, BVK), resulting in either postponed house purchases or increased dependence on parents' and families' support willingness and financial capacity. Indeed, as in other mature homeowner societies, access to homeownership has become more family-dependent than before the GFC (Druta \& Ronald, 2017); and, again like in other societies (Hamnett, 1999; Stephens, 2007), the contemporary homeownership model creates insiders and outsiders, i.e. winners and losers. The starkest division appears between those who benefit from house price inflation/appreciation, most explicitly through inheritance, and those who are locked out of the benefits of homeownership, either because they are unable to buy a house or because they are faced with negative equity.

Traditionally, in conservative housing finance regimes, such as in Belgium (see next subsection), mortgages were granted based on one income in the household, typically the male breadwinner. However, today it is necessary for most households to bring in two incomes to 
qualify for a mortgage loan large enough to buy a house, thereby rendering housing too expensive for most single persons (e.g., Interview Tobback, SPA). At the same time, entering into traditional marriages at a young age has become less frequent and other lifestyles are becoming predominant in a postmodern, pluralist society, often extending the period living as singles. Having a housing model based on two, stable income-generating household members no longer matches the needs of an ever-increasing share of the population. Many policy stakeholders see a need to make homeownership more affordable for households currently locked out.

\subsection{Conservative Housing Finance}

Across the board, policy stakeholders consider the Belgian housing finance system and practice to be 'conservative', and this is explicitly seen as a good thing (see also Winters \& Van den Broeck, 2016). Most mortgages have full amortization and scheduled payments, with most households knowing exactly what they have to pay throughout the lifetime of the entire mortgage contract. Taken together with the free insurance for mortgage repayments in case of sickness and unemployment, these factors explain the fact that 'we have very few mortgage arrears in this country' (Interview De Decker, Professor). Additionally, there are no 'exotic' mortgage products. As a result, the interviewees see a well-functioning and stable homeownership model.

However, the increasing household debt levels are an important development that could challenge the conservative housing finance model, especially as it is concentrated in the lowerincome quintiles (Du Caju, 2017). At the same time, the National Bank continues a policy of expanding household debt: 'We are [one] of the countries that are still leveraging up in an active way' (Interview Dewachter, NBB). This policy is adverse to conservative practises in which especially lower-income households gets more indebted. Also, the growth of household debt in Belgium is a clear sign that the banks are applying looser credit standards than before. The underlying reason for the uptake of more household debt is rather obvious. On the one hand, housing has become more expensive in real terms, and households, especially lower-income households, need to take out ever-larger mortgages in order to afford homeownership; on the other, lenders and the National Bank have also enabled and facilitated this.

\subsection{Asset-Based Welfare}

Becoming an outright homeowner was seen as important by all interviewees. As pensions in Belgium are rather low compared to other countries and the cost of renting is high, stakeholders found it crucial to secure a rent-free retirement. The interview with the housing expert from the 
Flemish Nationalist Party emphasized this point: 'If you are with pension [i.e. retired] and you need to pay rent, your life quality will drop immediately' (Interview Dirckx, N-VA). During the Fordist period, cheap land and homeownership grants, combined with stable employment regime enabled Belgium to develop into a nation of mass homeownership, allowing a substantial number of baby boomers to become outright homeowners (De Decker, 2013; Meeus \& De Decker, 2013). However, studies also show that Flemish homeowners do not see their home as an asset for welfare needs but rely on the state instead (De Decker \& Dewilde, 2010). Therefore, ABW in Belgium is only limited to the extent of living rent-free during old age.

The discourse of ABW is perhaps the strongest discourse in Flanders, rooted as it is in centuries of housing ideology and practice, as put forward by a representative of the Christian Democrats:

When you're a homeowner, you are much less likely to be poor when you're old. That is for certain, and, we mean, it is a wise decision to go for homeownership. (Interview Van Butsel, CD\&V)

However, the idea of ABW contains contradictions in which more expensive housing together with macro- and micro-economic developments make it increasingly difficult to become outright homeowners. Indeed, the discourses of house price inflation, and access and affordability to homeownership are contradictory to $\mathrm{ABW}$, as more expensive housing makes it more difficult to enjoy the benefits of being an outright homeowner. For ABW to function as a policy that can supplement low pensions, the government needs to secure access to homeownership for all social groups, including low-income households, who are currently either heavily mortgaged or find it more difficult to access homeownership. This implies that ABW policies should be expanded to enable wider access, but this will likely inflate house prices even further and thereby increase tensions due to contradicting tendencies in the future. Furthermore, there is a 'Really Big Contradiction' between the discourses of ABW and tenure neutrality, in which the emphasis on ABW undermines the discourse and possibility of becoming tenure neutral.

\subsection{Tenure Neutrality}

Tenure neutrality is a discourse that is emphasized by most interviewees since it is no longer seen as legitimate to promote and favour homeownership above other tenures. For the Flemish Department of Housing, for example, it became clear that any explicit goal for homeownership is not on the agenda anymore:

We have housing goals in the Flemish Housing Code, different goals, but homeownership is not one of them. We have affordability, we have good quality and good housing 
environment. And, some also added equal opportunities and integration, but we don't have homeownership as a goal anymore. (Interview Geurts, Flemish Housing Agency)

Despite homeownership being considered a very sensitive issue that is not explicitly discussed in the political domain, it is becoming clear that there is a need for tenure neutrality in order to meet contemporary housing demand in the face of a changing labour market. One way to circumvent this contradiction is not speak about homeownership and instead discuss policies that can make other tenures alternatives to homeownership. As the housing policy advisor of the Liberals put it: 'I think a lot of people now know someone who does not fit into the traditional homeownership model' (Interview Vandekerckhoeve, Open VLD), a feeling shared by other interviewees.

There is a clear contradiction between the well-established discourse of ABW and the emerging discourse of tenure neutrality. How can the government ever be tenure neutral when it is heavily emphasizing outright homeownership as crucial for avoiding old age poverty? ABW continues to be considered the safest route to live rent- and mortgage-free during old age, and there appears to be no intention to increase pensions to allow older households to afford rental prices. At the same time, a recent study shows that suburban and exurban homeowners do not support any changes in housing and planning policies (Bervoets et al., 2015). Both the study on homeowners and our interviews with stakeholders reveal that most people still consider the Belgian housing model to work well and homeownership being important 'to do well in life'. In sum, tenure neutrality is supported discursively, but without a willingness to question the hegemony of homeownership.

\section{Conclusion}

In this paper we discussed four contemporary policy discourses of homeownership as the model of tenure in Flanders: affordable homeownership, conservative housing finance, asset-based welfare and tenure neutrality. Analysing and discussing how the discourses are currently reproduced, we have uncovered a number of contradictions between the different discourses as well as between the discourses, on the one hand, and the reality, on the other.

First, house price appreciation is both a cause supporting and a factor undermining the Belgian homeownership model. On the one hand, years of house price increases have confirmed many people's ideas that buying a house is a good and safe investment that performs better than renting one and helps to build housing wealth. On the other hand, however, house price inflation in real terms and deposit requirements are causing more difficulties for younger people to enter the homeownership market. Those who inherited money or property can benefit from house price inflation and appreciation through intergenerational transfers. Securing homeownership has, 
therefore, become increasingly family-dependent and as a result more unequal, as not everyone can rely on inheritance and intergenerational transfers. As a result of these contradictions of financialized homeownership, housing systems may have 'become a vehicle for growing inequality rather than widespread financial security' (Arundel, 2017: 195). Indeed, the homeownership model is an engine of inequality. Moreover, it is a concern that homeownership affordability is calculated based on two stable incomes in the household, despite the fact that stable jobs are less common than in the Fordist accumulation period of capitalism, and more people live a long part of their lives as singles in a postmodern society.

Yet, and second, there is high self-confidence in the conservative housing finance model in Flanders and Belgium, but it is argued that it is currently challenged by increased financialization by the National Bank of Belgium in which they are consciously leveraging up and indebting Belgian households, particularly lower-income households.

Third, ABW is seen as very important for avoiding poverty in old age. However, it has become a less viable option since it is more difficult to become a homeowner-housing is expensive; jobs are less stable, and Belgian households are more indebted. Becoming an outright homeowner is ever more challenging, and the promise of rent- and mortgage-free living are increasingly slipping out of reach for low-income households. There is an intrinsic contradiction between house price inflation and $\mathrm{ABW}$, as house price inflation makes it more difficult for future generations to become outright homeowners.

Fourth, it is impossible to be truly tenure neutral in a housing model where ABW is so heavily emphasized; it is considered a 'no-go' to challenge the hegemony of homeownership. In short, we argue that there is not only a 'Really Big Trade-Off Between Homeownership and Welfare' (Kemeny, 1981) but also a 'Really Big Contradiction' between the current reproduction of the discourses of $\mathrm{ABW}$ and tenure neutrality. If the discourse of tenure neutrality really gets embedded in Flemish policies and housing practices, the role of homeownership in Flemish society could diminish. A society where homeownership is a possible - but not the only-route to adequate housing is currently wishful thinking. More dynamic and fair housing opportunities for everyone need to be created, not only in discourse but also in political, social and economic practices. This shift also applies to the provision of sufficient pensions that enable retired households to cover housing expenses, even when they are not outright homeowners. In other words, the hegemonic status of homeownership and ABW should be examined and questioned.

Future studies could look into the similarities between Flanders, Brussels and Wallonia, but also between Flanders and both mature and financialized homeowner societies. In addition, studies should look into the National Bank's policy of consciously leveraging up and thereby indebting Belgian households. As shared by the interviewee from the National Bank, the 
institution is starting to become more vigilant regarding the increased debt-to-GDP level; however, as it seems that there is no other option than continuing to leverage up, financialization will likely increase, in particular for lower-income households.

Discourses do not necessarily change because the reality they seek to depict or reflect has changed. Indeed, in a Habermasian or critical realist take on discourse, it could be argued that discourses are employed to mediate the very contradictions of society, with secondary discourses being mobilized to maintain the logic of the central discourse (Fairclough, 2003). Smith (2019) suggests that even the subprime mortgage crisis did not undermine the discourses supporting homeownership in the US. In the case of Belgium, we also do not see strong potential for 'The Really Big Contradiction' to undermine the Belgian homeownership model. Lack of access and affordability are generally not seen as reasons to question the homeownership model but rather to expand it further. Comparatively speaking, Belgians have a lot of savings, and much of these eventually are invested in housing. The capital and value in the housing market will be inherited; however, this accumulation of assets comes at a cost of growing inequality. The future of the homeownership model in Flanders will depend on future measures and interventions taken by the government. How homeownership and inheritance are taxed are crucial key factors for either mitigating or reproducing inequalities and polarisation. Housing in Flanders risks becoming a polarizing issue due to the growing gap between owners and tenants.

The discourse of homeownership that is prevalent in Flanders hails back to the days when houses were typically owned outright and were appreciated more for the ontological security they provide than as assets to be invested in (cf. Forrest \& Hirayama, 2015). Although Belgians, by and large, still see houses firstly as homes and only secondly as assets, they underwrite the basis premises of $\mathrm{ABW}$ and the price appreciation and wealth effects that allow them to help younger generations acquire a home as well. Yet Flanders is also faced with 'The Really Big Contradiction' between the discourses that support homeownership as the 'normalized' form of tenure in Belgium and the reality of declining affordability, progressively less conservative housing finance, the fractions and inequalities of housing-based wealth, and the absence of tenure neutrality. The financialized homeownership model is undermining the stability of homeowner realities and practices in Flanders - and Flanders and Belgium have only a moderately financialized homeownership system. The financialization of homeownership has progressed much further in many Anglophone and Scandinavian countries as well as the Netherlands. We finish our paper by suggesting that 'The Really Big Contradiction' between the nature of the discourses that support homeownership and the reality of declining affordability and inequalities of housing-based wealth will be more visible in highly financialized homeownership societies. 


\section{References}

Aalbers, M.B. (2008). The Financialization of Home and the Mortgage Market Crisis. Competition \& Change, 12(2), 148-166.

Aalbers, M.B. (2015). The Great Moderation, the Great Excess and the global housing crisis. Journal of Housing Policy, 15(1), 43-60.

Aalbers, M.B. (2016). The Financialization of Housing: A Political Economy Approach. London: Routledge.

Aalbers, M.B. (2019) Financial geography II: Financial geographies of housing and real estate. Progress in Human Geography, 43(2), 376-387.

Aalbers, M.B., Hochstenbach, C., Bosma, J. \& Fernandez, R. (2020). The death and life of private landlordism: How financialized homeownership gave birth to the buy-to-let market. Housing, Theory and Society, in press.

Angermuller, J. (2015). Discourse studies. In: Wright, J. D. (ed.): International Encyclopedia of the Social \& Behavioral Sciences, Second Edition, pp. 510-515. Amsterdam: Elsevier.

Arundel, R. (2017). Equity inequity: Housing wealth inequality, inter and intra-generational divergences, and the rise of private landlordism. Housing, Theory and Society 34(2), 176-200.

Arundel, R., \& Doling, J. (2017). The end of mass homeownership? Changes in labour markets and housing tenure opportunities across Europe. Journal of Housing and the Built Environment, $32(4), 649-672$.

Berry, M. (1986). Housing provision and class relations under capitalism: Some implications of recent Marxist class analysis. Housing Studies, 1(2), 109-121.

Bervoets, W., van de Weijer, M., Vanneste, D., Vanderstraeten, L., Ryckewaert, M., \& Heynen, H. (2015). Towards a sustainable transformation of the detached houses in peri-urban Flanders, Belgium. Journal of Urbanism: International Research on Placemaking and Urban Sustainability, 8(3), $302-330$.

Boughton, J. (2018). Municipal Dreams: The Rise and Fall of Council Housing. London: Verso.

Buyst, E. (1992). An Economic History of Residential Building in Belgium Between 1890 and 1961. Koninklijke Academie voor Letteren, Wetenschappen en Schone Kunsten van België; Brussel.

De Caigny, S. (2010). Bouwen aan een nieuwe thuis: wooncultuur in Vlaanderen tijdens het interbellum [Building a new home: housing culture in Flanders during the interbellum]. Universitaire Pers Leuven.

De Decker, P. (2001). Jammed between housing and property rights: Belgian private renting in perspective. International Journal of Housing Policy, 1(1), 17-39.

De Decker, P. (2011). Understanding housing sprawl: the case of Flanders, Belgium. Environment and Planning A, 43(7), 1634-1654.

De Decker, P. (2013). Eigen woning: geldmachine of pensioensparen? [The owned home: money machine or pension savings?]. Antwerpen: Maklu.

De Decker, P., \& Dewilde, C. (2010). Home-ownership and asset-based welfare: the case of Belgium. Journal of Housing and the Built Environment, 25(2), 243-262.

De Decker, P., Meulemans, B., \& Geurts, V. (1997). Trouble in paradise? On increasing housing problems in Flanders. Netherlands Journal of Housing and the Built Environment, 12(3), 281-305.

Di Feliciantonio, C. (2016). Subjectification in times of indebtedness and neoliberal/austerity urbanism. Antipode, 48(5), 1206-1227. 
Dupuis, A., \& Thorns, D.C. (1998). Home, home ownership and the search for ontological security. The Sociological Review, 46(1), 24-47.

Deschamps, L. (1997). Het sociale huisvestingsbeleid vanaf WO II tot heden. Van missie tot resultaten: de basisgegevens. [Social housing policies from World War II till now. From mission to results: the basic facts]. Brussel: Vlaamse Huisvestingsmaatschappij, 253-294.

Dewilde, C., \& Raeymaeckers, P. (2008). The trade-off between home-ownership and pensions: individual and institutional determinants of old-age poverty. Ageing \& Society, 28(6), 805-830.

Dewilde, C., \& Ronald, R. (Eds) (2017). Housing Wealth and Welfare. Cheltenham: Edward Elgar.

Diaz-Serrano, L. (2009). Disentangling the housing satisfaction puzzle: Does homeownership really matter? Journal of Economic Psychology, 30(5), 745-755.

Doling, J., \& Ronald, R. (2010). Property-based welfare and European homeowners: how would housing perform as a pension? Journal of Housing and the Built Environment, 25(2), 227-241.

Druta, O., \& Ronald, R. (2017). Young adults' pathways into homeownership and the negotiation of intrafamily support: A home, the ideal gift. Sociology, 51(4), 783-799.

Du Caju, P. (2017). Pockets of Risk in the Belgian Mortgage Market: Evidence from the Household Finance and Consumption Survey (HFCS). NBB Working Paper No. 332. Brussels: National Bank of Belgium.

Du Caju, P., Emiris, M., Piette, C., \& Zachary, M. (2018). Shedding New Light on the Mortgage Debt of Households in Belgium. Brussels: National Bank of Belgium.

Easthope, H. (2004). A place called home. Housing, Theory and Society, 21(3), 128-138.

Elsinga, M., \& Hoekstra, J. (2005). Homeownership and housing satisfaction. Journal of Housing and the Built Environment, 20(4), 401-424.

Fairclogh, N. (1992). Discourse and Social Change. Cambridge: Polity.

Fernandez, R. \& Aalbers, M.B. (2016). Financialization and housing: Between globalization and varieties of capitalism. Competition and Change, 20(2), 71-88.

Flowerdew, R., \& Martin, D. (Eds). (2005). Methods in Human Geography: A Guide for Students Doing a Research Project. Second Edition. Harlow: Pearson Education.

Forrest, R. \& Hirayama, Y. (2015). The financialisation of the social project: Embedded liberalism, neoliberalism and home homeownership. Urban Studies, 52(2), 233-244.

Forrest, R. \& Hirayama, Y. (2018). Late homeownership and social re-stratification. Economy and Society, 47(2), 257-279.

Forrest, R., Murie, A., \& Williams, P. (1990). Homeownership: Differentiation, and Fragmentation. London: Unwin Hyman.

Foucault, M. (1972). The Archaeology of Knowledge \& the Discourse on Language. New York: Pantheon.

García-Lamarca, M., \& Kaika, M. (2016). 'Mortgaged lives': the biopolitics of debt and housing financialisation. Transactions of the Institute of British Geographers, 41(3), 313-327.

Goossens, L. (1983). Het sociaal huisvestingsbeleid in België. Een historisch-sociologische analyse van de woonproblematiek sinds 1830 [Social housing policies in Belgium. A historical-sociological analysis of housing problems since 1830]. Tijdschrift Voor Sociale Wetenschappen, 28(2), 83110.

Gurney, C.M. (1997). “... Half of me was satisfied”: Making sense of home through episodic ethnographies. Women's Studies International Forum, 20(3), 373-386.

Gurney, C.M. (1999). Pride and prejudice: Discourses of normalisation in public and private accounts of homeownership. Housing Studies, 14(2), 163-183.

Habermas, J. (1985). The Theory of Communicative Action. Boston: Beacon Press. 
Haffner, M., \& Winters, S. (2016). Homeownership taxation in Flanders: moving towards 'optimal taxation'? International Journal of Housing Policy, 16(4), 473-490.

Hamnett, C. (1999). Winners and Losers: Home-ownership in Modern Britain. London: UCL Press.

Hay, C. (2004). Common trajectories, variable paces, divergent outcomes? Models of European capitalism under conditions of complex economic interdependence. Review of International Political Economy, 11(2), 231-261.

Hilgers, J. (2018). Financial Stability Report 2018. Brussels: National Bank of Belgium.

Hiscock, R., Kearns, A., MacIntyre, S., \& Ellaway, A. (2001). Ontological security and psycho-social benefits from the home: Qualitative evidence on issues of tenure. Housing, Theory and Society, $18(1-2), 50-66$.

Hodkinson, S. (2019). Safe as Houses: Private Greed, Political Negligence and Housing Policy After Grenfell. Manchester: Manchester University Press.

Hoolachan, J., McKee, K., Moore, T., \& Soaita, A.M. (2017). 'Generation rent' and the ability to 'settle down': economic and geographical variation in young people's housing transitions. Journal of Youth Studies, 20(1), 63-78.

Keller, R. (2005). Wissenssoziologische Diskursanalyse: Grundlegung eines Forschungsprogramms [Knowledge sociological discourse analysis: Foundation of a research program]. Wiesbaden: VS.

Kemeny, J. (1981). The Myth of Home-Ownership: Private versus Public Choices in Housing Tenure. London: Routledge.

Kemp, P.A. (2015). Private renting after the global financial crisis. Housing Studies, 30(4), 601-620.

Kesteloot, C., \& De Maesschalck, F. (2001). Anti-urbanism in Flanders: the political and social consequences of a spatial class struggle strategy. Belgeo. Revue Belge de Géographie, (1-2), 4162.

Kwak, N. (2015). A World of Homeowners: American Power and the Politics of Housing Aid. Chicago: University of Chicago Press.

Langley, P. (2006). The making of investor subjects in Anglo-American pensions. Environment and Planning D: Society and Space, 24(6), 919-934.

Lazzarato, M. (2012). The Making of the Indebted man: An Essay on the Neoliberal Condition. Los Angeles: Semiotext(e).

Lyotard, J.F. (1984). The Postmodern Condition: A Report on Knowledge. Minneapolis: University of Minnesota Press.

Malpass, P. (2008). Housing and the New Welfare State: Wobbly Pillar or Cornerstone? Housing Studies, 23(1), 1-19.

McKee, K., Moore, T., Soita, A. \& Crawford, J. (2017). 'Generation Rent' and the fallacy of choice. International Journal of Urban and Regional Research, 41(2), 318-333.

Meeus, B., \& De Decker, P. (2013). De geest van suburbia [The ghost of suburbia]. Antwerpen: Maklu.

Montgomerie, J., \& Büdenbender, M. (2015). Round the houses: Homeownership and failures of assetbased welfare in the United Kingdom. New Political Economy, 20(3), 386-405.

Mougenot, C. (1988). Promoting the single-family house in Belgium: the social construction of model housing. International Journal of Urban and Regional Research, 12(4), 531-549.

Munro, M. (2018). House price inflation in the news: a critical discourse analysis of newspaper coverage in the UK. Housing Studies, 33(7), 1085-1105.

Norris, M. (2016). Property, Family and the Irish Welfare State, Property, Family and the Irish Welfare State. Basingstoke: Palgrave Macmillan. 
Rohe, W.M., \& Stegman, M.A. (1994). The effects of homeownership: On the self-esteem, perceived control and life satisfaction of low-income people. Journal of the American Planning Association, $60(2), 173-184$.

Ronald, R. (2008). The Ideology of Homeownership: Homeowner Societies and the Role of Housing. Basingstoke: Palgrave Macmillan.

Ronald, R. \& Kadi, J. (2018). The revival of private landlords in Britain's post-homeownership society. New Political Economy 23(6), 786-803.

Ryckewaert, M. (2011). Building the Economic Backbone of the Belgian Welfare State. Infrastructure, Planning and Architecture 1945-1973. Rotterdam: 010.

Saunders, P. (1990). A Nation of Homeowners. London: Unwin Hyman,.

Schwartz, H.M., \& Seabrooke, L. (2009). The Politics of Housing Booms and Busts. Basingstoke: Palgrave Macmillan.

Smets, M. (1977). De ontwikkeling van de tuinwijkgedachte in België. Een overzicht van de Belgische volkswoningbouw 1830-1930 [The development of garden city ideas in Belgium. An overview of Belgian social housing 1830-1930]. Brussel: Mardaga.

Smith, B. (2019). Life, liberty, and a house in the suburbs. The political construction of the homeownership model of happiness in the United States. Revue Interventions Économiques, 62, $1-18$.

Smith, S.J., Searle, B.A. \& Cook, N. (2009). Rethinking the risks of home-ownership. Journal of Social Policy, 38(1), 83-102.

Statistiek Vlaanderen (2020). Eigendomsstatuut [Property status]. URL: https:// www.statistiekvlaanderen.be/nl/eigendomsstatuut (Accessed 14 April 2020).

Stephens, M. (2007). Mortgage market deregulation and its consequences, Housing Studies, 22(2), 201220.

Verhofstadt, G. (2002). De vierde golf [The fourth wave]. Antwerp: Houtekiet.

Whitehead, C., Scanlon, K., \& Lunde, J. (2014). The Impact of the Financial Crisis on European Housing Systems: A Review. Stockholm: Swedish Institute for European Policy Studies.

Whitehead, C., \& Williams, P. (2017). Changes in the regulation and control of mortgage markets and access to owner-occupation among younger households. OECD Social, Employment and Migration Working Papers, No. 196. Paris: OECD.

Winters, S. (2013). Belgian state reform as an opportunity to reorient Flemish housing policy. International Journal of Housing Policy, 13(1), 90-99.

Winters, S., \& Van den Broeck, K. (2016). Milestones in 25 Years of Housing Finance in Belgium. In Lunde, J., \& Whitehead, C. (Eds). Milestones in European Housing Finance, pp. 75-92. Oxford: John Wiley \& Sons.

Witte, E. (1990). Politiek en democratie: omtrent de werking van de westerse democratieën in de 19de en $20 d e$ eeuw [Politics and democracy: on the workings of western democracies in the 19th and 20th centuries]. Brussel: VUB Press.

Woonbeleidsplan Vlaanderen [Housing Policy Plan Flanders]. (2018, March 23). Brussel: Flemish Government.

Yanow, D. (2000) Conducting Interpretive Policy Analysis. Thousand Oaks, CA: Sage. 